\title{
GERMINATION OF SEEDS FROM HERBACEOUS PLANTS ARTIFICIALLY STORED IN CERRADO SOIL
}

\author{
SASSAKI, R. M., RONDON, J. N., ZAIDAN, L. B. P. and FELIPPE, G. M. \\ Seção de Fisiologia e Bioquímica de Plantas, Instituto de Botânica, C.P. 4005, \\ CEP 01061-970, São Paulo, SP, Brazil \\ Correspondence to: Lilian B. P. Zaidan, Seção de Fisiologia e Bioquímica de Plantas, Instituto de Botânica, \\ C.P. 4005, CEP 01061-970, São Paulo, SP, Brazil \\ Received March 03, 1997 - Accepted November 18, 1998 - Distributed June 30, 1999
}

(With 5 figures)

\begin{abstract}
The germination of three cerrado herbaceous species: Bidens gardneri, Vernonia herbacea (Asteraceae) and Psychotria barbiflora (Rubiaceae) was studied using seeds stored in cerrado soil and in refrigerator at $4^{\circ} \mathrm{C}$. The field experiment was carried out at a preserved area of cerrado, the Reserva Biológica e Estação Experimental de Mogi-Guaçu, State of São Paulo, Brazil. The soil was collected in the same cerrado where the experiment was carried out. The achenes of Bidens gardneri are light sensitive, but this sensitivity disappeared when the achenes were stored in soil. With 3 months storage in cerrado soil no differences in germination in light or darkness were detected. The number of intact achenes retrieved from storage in soil decreased with increasing time of storage. A large number of seeds had already germinated during the 3 months storage in soil. The longevity of seeds of this species stored for nearly 10 years at $4^{\circ} \mathrm{C}$ was checked: the achenes were viable for a long period of time but less than 10 years. Intact achenes of Vernonia herbacea could be retrieved from the soil only with 1 month storage. Germination was always very low and only $15 \%$ of the achenes possessed embryos. The number of intact seeds of Psychotria barbiflora decreased the longer the period of storage in soil. Germination of seeds stored at $4^{\circ} \mathrm{C}$ or in the soil was always very low. From the germination studies of stored seeds in cerrado it can be concluded that Vernonia herbacea does not form a seed bank and Bidens gardneri and Psychotria barbiflora may form a temporary seed bank in cerrado.
\end{abstract}

Key words: Bidens gardneri, Vernonia herbacea, Psychotria barbiflora, seed viability, light sensitivity.

\section{RESUMO \\ Germinação de sementes de plantas herbáceas artificialmente armazenadas em solo de cerrado}

Foi estudada a germinação de sementes armazenadas em geladeira a $4^{\circ} \mathrm{C}$ e em solo de cerrado de três espécies herbáceas do cerrado: Bidens gardneri, Vernonia herbacea (Asteraceae) e Psychotria barbiflora (Rubiaceae). O trabalho de campo foi realizado em uma área preservada de cerrado, a Reserva Biológica e Estação Experimental de Mogi-Guaçu, Estado de São Paulo, Brasil. O solo utilizado era proveniente do mesmo cerrado em que o experimento de campo foi realizado. Os aquênios de Bidens gardneri apresentam fotoblastismo positivo, mas a sensibilidade à luz desapareceu quando eles foram armazenados em solo do cerrado. Não houve diferença na germinação em luz ou escuro quando os aquênios foram armazenados por 3 meses em solo. $\mathrm{O}$ número de aquênios intactos diminuiu à medida que o período de estocagem no solo aumentou; um grande número de aquênios germinou durante esses 3 meses de armazenamento. Foi verificada a longevidade de aquênios dessa espécie 
armazenados a $4^{\circ} \mathrm{C}$ por cerca de 10 anos: os aquênios foram mantidos viáveis por muito tempo, mas sempre em período inferior a 10 anos. Aquênios intactos de Vernonia herbacea só foram encontrados quando o armazenamento no solo foi de apenas 1 mês. A germinação desta espécie foi sempre baixa, independente do armazenamento, e apenas $15 \%$ dos aquênios apresentaram embriões. O número de sementes intactas de Psychotria barbiflora decresceu à medida que aumentou o período de estocagem. A germinação de sementes armazenadas a $4^{\circ} \mathrm{C}$ ou em solo foi sempre muito baixa. Dos resultados obtidos aqui, pode-se concluir que Vernonia herbacea não forma banco de sementes e que Bidens gardneri e Psychotria barbiflora podem formar um banco de sementes temporário no cerrado.

Palavras-chave: Bidens gardneri, Vernonia herbacea, Psychotria barbiflora, viabilidade, fotoblastismo.

\section{INTRODUCTION}

Soil seed banks are repositories of the vegetation of a certain region. They can also contain species not always found in the aboveground vegetation (Champness \& Morris, 1948; Bennington et al., 1991). This divergence between the species composition of the soil seed bank and the aboveground vegetation demonstrates the necessity of sampling to obtain a representative estimate of the real vascular plant diversity (Berge \& Hestmark, 1997).

But even careful sampling does not take into account those species that produce seeds unable to survive wet storage. Some seeds do not show dormancy and if they have permeable coats they will germinate - these species will not be part of the soil seed bank.

Thus it is also very important in studies involving the physiology of germination in seeds artificially stored in soil to know their survival capacity.

Cerrado is the natural cover of $22 \%$ of the land area of Brazil. Most of the cerrado is subjected to prolonged winter drought. The vegetation is predominantly sclerophyllous.

Trees and shrubs are not very tall presenting short thick branches with a characteristic tortuous appearance (Zaidan \& Felippe, 1994). The herbaceous component represents about $77 \%$ of the cerrado vegetation (Mantovani \& Martins, 1988).

The objective of this work was to examine the viability of seeds from three herbaceous species found in the cerrado, and to determine whether storage in soil leads to the accumulation of a viable seed bank. In addition more extended studies were made of viability and response to light of achenes of one species following prolonged storage at 4rC.

\section{MATERIAL AND METHODS}

Achenes of Bidens gardneri Baker (Asteraceae) and fruits of Psychotria barbiflora DC (Rubiaceae) were collected at the cerrado in Itirapina, state of São Paulo and achenes of Vernonia herbacea (Vell.) Rusby (Asteraceae) in the cerrado at the Reserva Biológica e Estação Experimental de Mogi-Guaçu (all 3 species occur at the Reserva). Voucher material of these species was deposited in the herbarium of the Instituto de Botânica, São Paulo.

The field experiment was carried out at a preserved area of cerrado, the Reserva Biológica e Estação Experimental de Mogi-Guaçu, located at Mogi-Guaçu, State of São Paulo, Brazil

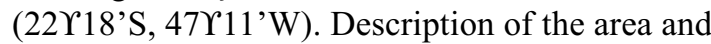
its vegetation is given by Mantovani \& Martins (1993) and Simabukuro et al. (1998). The chemical and physical analyses of the soil used are presented in Tables 1 and 2. Fig. 1 shows the rainfall and the temperature of the region in the period of the experiment.

Seeds (fruits from now on called seeds) were stored at two conditions. The control set was kept in the refrigerator at 4rC in closed bottles ("dry conditions").

The experimental set was stored mixed with superficial soil from the site where the experiments were carried out and kept in containers $(10 \times 15$ $\mathrm{cm})$ prepared with a gauze-type black nylon cloth with very fine mesh ("Sombrite"); after sealing, the containers were buried between 10 and $15 \mathrm{~cm}$ deep.

The containers were removed from the soil at 1-, 3-, 6-, 9- and 12-month intervals. The experiment for each species was stopped when intact seeds were no longer found. 

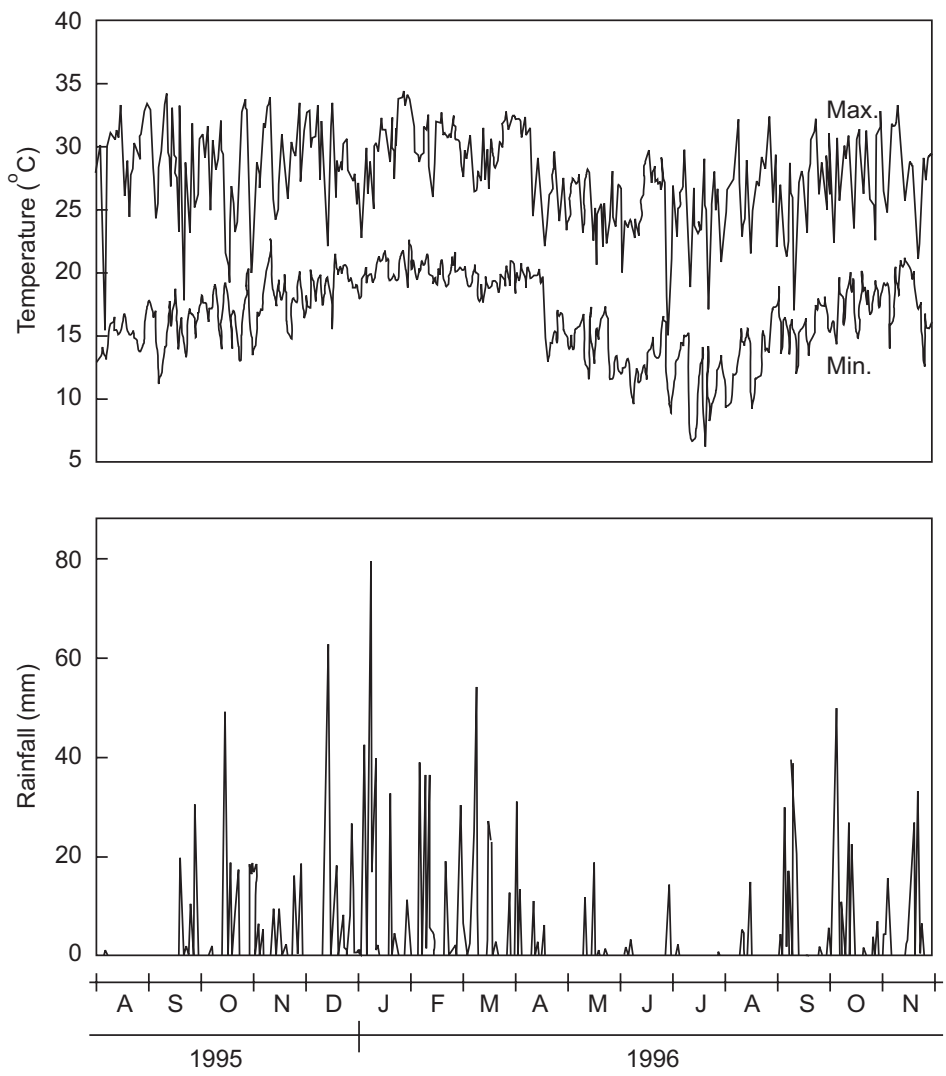

Fig. 1 - Temperature $\left({ }^{\circ} \mathrm{C}\right)$ and rainfall $(\mathrm{mm})$ between August 1995 and November 1996. Reserva Biológica e Estação Experimental de Mogi-Guaçu, Mogi-Guaçu, State of São Paulo, Brazil (according to Instituto Agronômico de Campinas, SP, Brazil).

TABLE 1

Chemical analysis of the cerrado soil samples from the Reserva Biológica e Estação Experimental de MogiGuaçu, according to the Departamento de Ciências do Solo, Universidade de São Paulo, Piracicaba, SP.

\begin{tabular}{|c|c|c|c|c|c|c|c|c|c|c|c|c|}
\hline \multirow{2}{*}{$\begin{array}{c}\text { Depth } \\
\text { (cm) }\end{array}$} & \multirow{2}{*}{$\underset{\left(\mu \mathbf{g . c m}^{-3}\right)}{\mathbf{P}_{\text {resin }}}$} & \multirow{2}{*}{$\begin{array}{l}\text { O M } \\
(\%)\end{array}$} & \multirow{2}{*}{$\mathrm{pHCaCl}_{2}$} & $\mathbf{K}^{+}$ & $\mathrm{Ca}^{2+}$ & $\mathbf{M g}^{2+}$ & $\mathbf{A l}^{3+}$ & $\mathbf{H}^{+}+\mathbf{A l}^{3+}$ & SB & CEC & $\mathbf{V}$ & $\mathbf{m}$ \\
\hline & & & & \multicolumn{5}{|c|}{ (meq. $\left.100 \mathrm{~cm}^{3}\right)$} & & & \multicolumn{2}{|c|}{$\%$} \\
\hline $0-5$ & 5 & 3.4 & 3.6 & 0.17 & 0.5 & 0.3 & 1.8 & 8.8 & 1.0 & 9.8 & 10 & 64 \\
\hline $5-10$ & 5 & 1.7 & 3.8 & 0.15 & 0.4 & 0.3 & 1.5 & 6.4 & 0.9 & 7.3 & 12 & 63 \\
\hline $10-15$ & 3 & 1.9 & 3.8 & 0.13 & 0.4 & 0.2 & 1.1 & 5.8 & 0.7 & 6.5 & 11 & 61 \\
\hline
\end{tabular}

$\mathrm{OM}=$ organic matter;

$\mathrm{H}^{+}+\mathrm{Al}^{3+}=$ potential acidity;

$\mathrm{SB}=$ sum of bases $=\mathrm{Ca}^{2+}+\mathrm{Mg}^{2+}+\mathrm{K}^{+}$

$\mathrm{CEC}=$ cationic exchange capacity $=\mathrm{SB}+\left(\mathrm{H}^{+}+\mathrm{Al}^{3+}\right)$;

$\mathrm{V}=$ saturation of bases $=\mathrm{SB} . \mathrm{CEC}^{-1} .100$;

$\mathrm{m}=$ saturation of $\mathrm{Al}^{3+}=\mathrm{Al} \times(\mathrm{SB}+\mathrm{Al})^{-1} \times 100$.

The containers were opened and the material retrieved and counted. Soon after the intact seeds were removed from their storage condition (soil or refrigerator) they were weighed for fresh weight (FW) determination; DW (dry weight) was obtained after drying the seeds at 80 rC for 48 hours. The moisture content (m.c.) was measured according to:

$$
\text { m.c. } \%=(F W-D W / F W) \infty 100
$$


TABLE 2

Physical analysis of the cerrado soil samples from the Reserva Biológica e Estação Experimental de MogiGuaçu, according to the Departamento de Ciências do Solo, Universidade de São Paulo, Piracicaba, SP.

\begin{tabular}{|c|c|c|c|c|c|c|c|c|c|}
\hline \multirow{2}{*}{$\begin{array}{c}\text { Depth } \\
\text { cm }\end{array}$} & \multicolumn{6}{|c|}{$\begin{array}{c}\text { Sand } \\
(\%)\end{array}$} & \multirow{2}{*}{$\begin{array}{c}\text { Silt }(\%) \\
\text { tot }\end{array}$} & \multirow{2}{*}{$\begin{array}{c}\text { clay }(\%) \\
\text { tot }\end{array}$} & \multirow[t]{2}{*}{$\begin{array}{c}\text { texture } \\
\text { class }\end{array}$} \\
\hline & ve & c & $\mathbf{m}$ & f & vf & tot & & & \\
\hline $0-5$ & - & 3 & 13 & 50 & 6 & 72 & 6 & 22 & m-sandy \\
\hline $5-10$ & - & 2 & 20 & 42 & 6 & 70 & 6 & 24 & m-sandy \\
\hline $10-15$ & - & 2 & 24 & 38 & 4 & 68 & 6 & 26 & m-clayey \\
\hline $\begin{array}{l}\mathrm{vc}=\text { very } \\
\mathrm{c}=\text { coarse } \\
\mathrm{m}=\text { medi } \\
\mathrm{f}=\text { fine } \\
\mathrm{vf}=\text { very } \\
\text { tot }=\text { total } \\
-=\text { not an }\end{array}$ & $\operatorname{arcs}$ & & & & & & & & \\
\hline
\end{tabular}

and was compared to the m.c. of the seeds kept in the refrigerator. Three replicates were always used. Germination of intact seeds was carried out in $9 \mathrm{~cm}$ diameter Petri dishes with two layers of wetted filter paper. Three replicates were used per treatment. Seeds kept in the refrigerator were always used as the control. Germination was carried out in growth-cabinets (BOD-FANEM) at 25rC, in darkness or in white fluorescent light, 437 $\mu \mathrm{W} . \mathrm{cm}^{-2} \cdot \mathrm{s}^{-1}$ at Petri dish level (Ruggiero \& Zaidan, 1997). Germination was checked daily. The seeds in darkness were checked using a safe green light (Labouriau \& Costa, 1976).

Achenes of Bidens gardneri Baker (210 per container) collected in 1995 were stored in cerrado soil in August 1995 and the containers were removed after 3, 6 and 9 months. For the germination tests and determination of the moisture content replicates of 30 seeds were used. In another experiment viability and light sensitivity were checked (germination carried out at 25rC) for seeds collected in different years (1988 to 1997) stored in closed bottles in darkness at 4rC for $6,17,28$, 43, 100 and 115 months. In seeds stored for 6 months germination was carried out in light and in darkness with the alternating temperatures of 20 rC and 30rC in cycles of 24 hours (12 hours of each temperature per 24 hour cycle).

Achenes of Vernonia herbacea (Vell) Rusby (1000 per container) were stored in cerrado soil in April 1996 and the containers removed after 1 and 3 months. For the germination tests and the determination of the moisture content replicates of 30 seeds were used. Seeds stored at 4rC were subjected to the tetrazolium test (Delouche et al., 1962). The seeds were kept in a solution of $1 \%$ tetrazolium salt at 30rC in darkness for 72 hours; 3 replicates of 100 seeds were used.

Fruits of Psychotria barbiflora DC (500 per container) were stored in cerrado soil in April 1996 for 1, 3 and 7 months. For the germination tests and the determination of the moisture content replicates of 50 seeds were used (seeds were removed from the fruits before the tests).

Germination values as percentages were transformed to angular values and the results compared by the Student's test at 0.05 probability (Snedecor, 1962).

\section{RESULTS}

\section{Bidens gardneri}

The germination of pre-stored seeds (achenes) was $31.8 \%$ in light and $0 \%$ in darkness (30 days from sowing). Germination in light increased to $80 \%$ after 3 months of storage either at $4 \mathrm{rC}$ or in soil (Figs. 2A, 2B). This high percentage of germination in light was maintained for the seeds kept in refrigerator for 6 months and fell down to $60 \%$ after 9 months storage; germination was always higher in light than in darkness. When the seeds were stored in soil the differences in percentage germination in light and in darkness decreased; after 3 months storage in cerrado soil (Fig. 2B) no differences in germination in light or darkness were detected. The number of intact achenes retrieved decreased with increasing 
time of storage in soil, few being recovered after 9 months storage. A large number of seeds had germinated during the 3 months storage in soil and as period of storage increased the number of germinated seeds also increased. After 3 months storage the moisture content was $10.6 \%$ for the seeds stored in refrigerator and $51.1 \%$ for those buried in cerrado soil. In another experiment, seeds of B. gardneri were stored in darkness at 4rC for $115,100,43,28,17$ and 6 months. No germination occurred either in light or in darkness for seeds stored for 115 months (nearly 10 years). The germination at 25rC of the seeds stored for $100,43,28$ and 17 months is shown in Fig. 3 (A, B, C, D) and the germination at 25rC and at the alternating temperatures of 20rC $-30 \mathrm{rC}$ of seeds stored for 6 months in Fig. 3 (E, F). The germination was very low in light with seeds stored for 100 months (less than 6\%) and no germination occurred in darkness (Fig. 3A). Thus very few seeds were viable after storage for 100 months. Fig. 3B shows that germination was also reduced with seeds stored for 43 months. Germination was very high for seeds stored for 28 and 17 months (Fig. 3C, D).
Germination at 25YC was very high with seeds stored for 6 months (Fig. 3E). When alternate temperatures of 20rC-30rC were used (Fig. 3F) the germination in light and darkness was similar in seeds stored for 6 months.

Since no significant differences were detected between germination in light and darkness it seems there is a decrease in light sensitivity of seeds of this species stored at 4rC for periods longer than 6 months.

\section{Vernonia herbacea}

The germination of newly collected seeds at the beginning of the storage experiment was very low: $11 \%$ in light and 3\% in darkness by 25 days from sowing. Only $28.3 \%$ intact seeds were found after storage in soil for 1 month.

After 3 months storage in soil no intact seeds were found. After 1 month storage in soil and in refrigerator the germination was again very low (Fig. 4A, B). Germination of seeds stored in refrigerator for 3 and 6 months is presented in Fig. 4 (C, D).

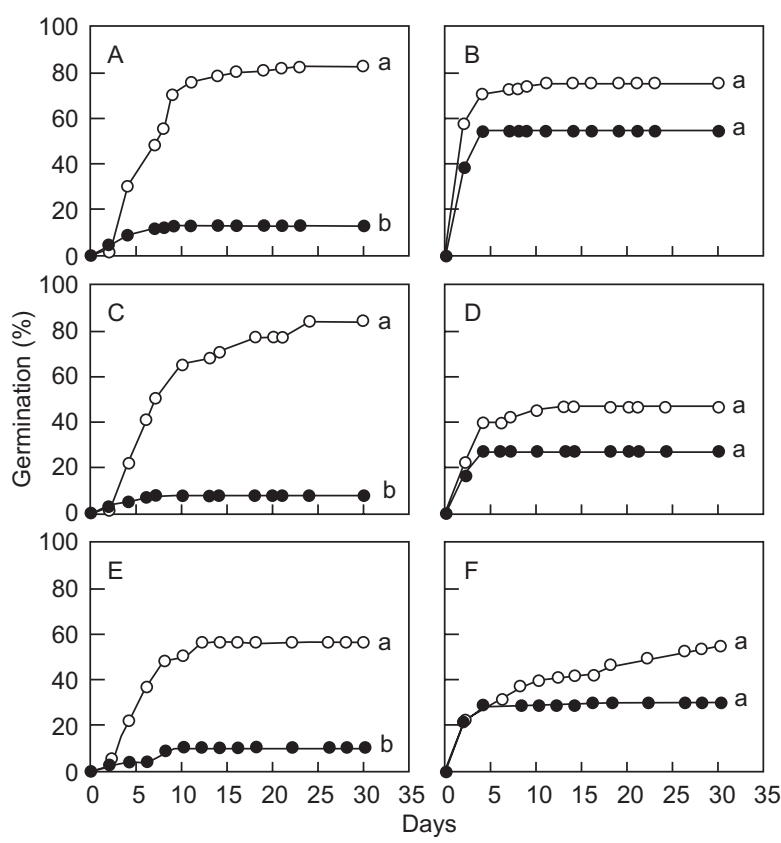

Fig. 2 - Germination of Bidens gardneri seeds stored at 4rC (A, C, E) and in cerrado soil at the Reserva Biológica e Estação Experimental de Mogi-Guaçu, Mogi-Guaçu, State of São Paulo, Brazil (B, D, F) during different periods: 3 (A, B), 6 (C, D) and 9 (E, F) months. Open symbols: germination at 25rC, in light; closed symbols: germination at 25rC, in darkness. Letters compare germination in darkness and light in each storage treatment. Germination values in light and darkness are different when the letters are different (Student's test ${ }_{95 \%}$ ). 

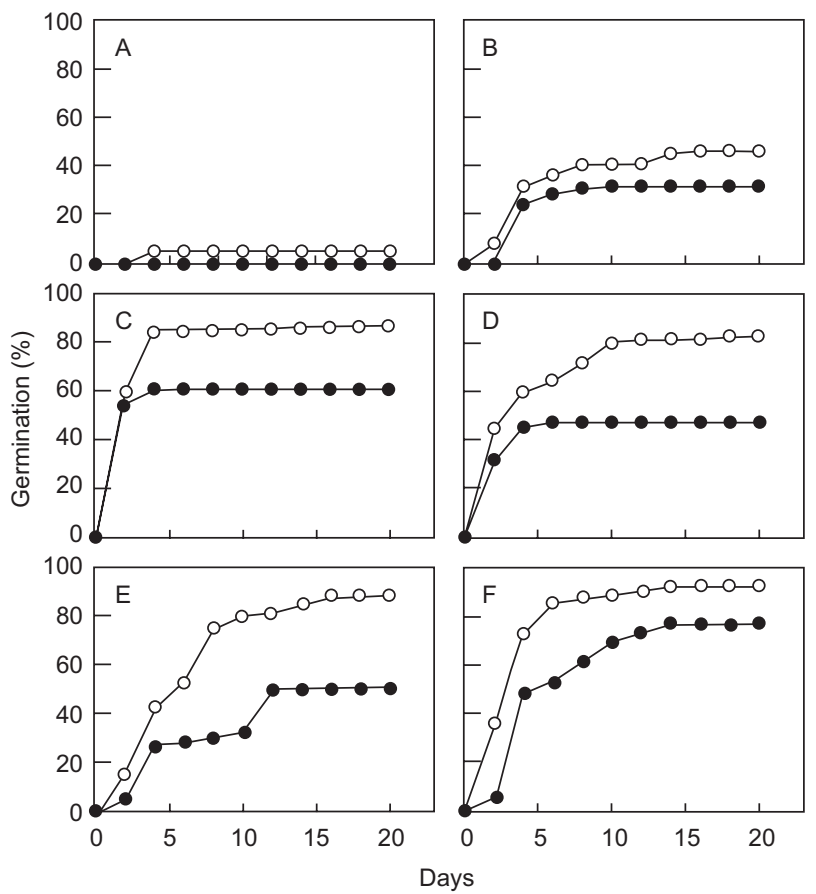

Fig. 3 - Germination at $25 \Upsilon \mathrm{C}$ in light and darkness of Bidens gardneri achenes stored at 4rC for 100 (A), 43 (B), 28 (C), 17 (D) and 6 months (E) and germination at 20rC-30rC in light and darkness of achenes stored for 6 months (F). Open symbols: germination in light; closed symbols: germination in darkness. No significant differences were seen between germination in light and darkness in all treatments according to the Student's test ${ }_{95 \%}$.

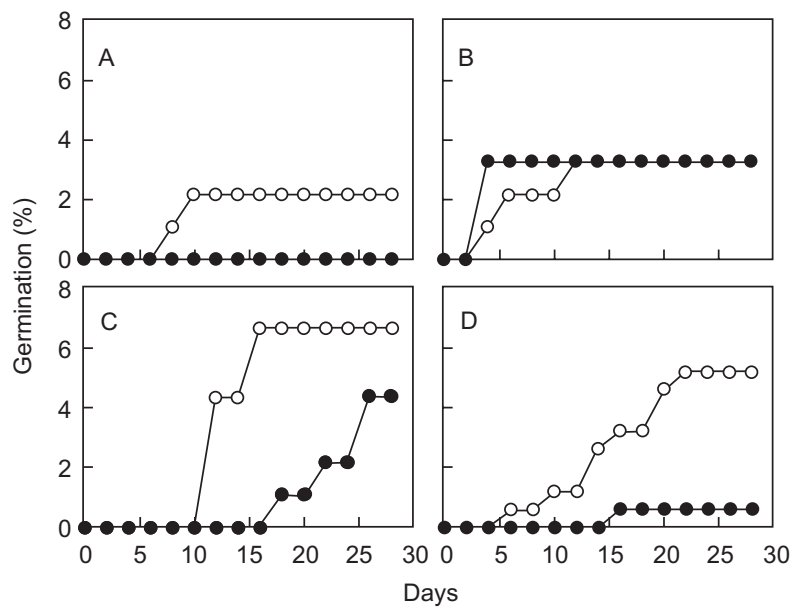

Fig. 4 - Germination of Vernonia herbacea seeds stored at 4rC in darkness and in cerrado soil in the cerrado at the Reserva Biológica e Estação Experimental de Mogi-Guaçu, Mogi-Guaçu, State of São Paulo, Brazil. Seeds stored for at 4 YC for 1 (A), 3 (C) and 6 (D) months; seeds stored in cerrado soil for 1 month (B). Open symbols: germination at 25rC, in light; closed symbols: germination at 25rC, in darkness. 
For the seeds stored at 4rC (refrigerator) germination was very low, but always higher when the seeds were kept in light. The germination of seeds stored in soil for 1 month was also low, and was the same when the germination test was done in light or darkness. The moisture content was $12.6 \%$ for seeds stored in refrigerator and $24 \%$ for the seeds stored in soil. The tetrazolium test showed that only $15 \%$ of the achenes possessed embryos.

\section{Psychotria barbiflora}

The germination of newly collected seeds of P. barbiflora was very low in light, being $8 \%$ on day 52 and $9 \%$ on day 96 from the beginning of the germination experiment (data not shown). In the soil the seeds were always free from the fruits and the number of intact seeds decreased with the longer the period of storage in soil (from 55\% after 1 month to $39 \%$ when the container was removed on the 7 th month). Around 5 seeds had already germinated in soil when the containers were re- moved. The moisture content was somewhat higher in seeds stored in soil (between 11\% and 17\%) than the seeds kept at 4 rC $(<10 \%)$.

Few seeds germinated in general (Fig. 5). Germination was checked for 52 days. Germination was low both in storage at 4rC and in cerrado soil. The effect of light upon germination was not clear. After 1 month storage in soil (Fig. 5b) germination was around $20 \%$ for seeds in light and in darkness and for seeds stored at 4rC and germinated in light; the germination in darkness of seeds stored for one month at 4 rC was reduced to around $10 \%$ (Fig. 5A). After three months storage (Figs. 5C, D) germination in light was reduced in seeds stored in soil in relation to storage at 4rC; no germination occurred in darkness for seeds kept either at 4rC or artificially buried in cerrado soil. When the containers were removed after 7 months (Figs. 5E, F), the intact seeds did not germinate in light and around $1 \%$ germinated in darkness; germination in light and in darkness of the control seeds went down to $7 \%$.

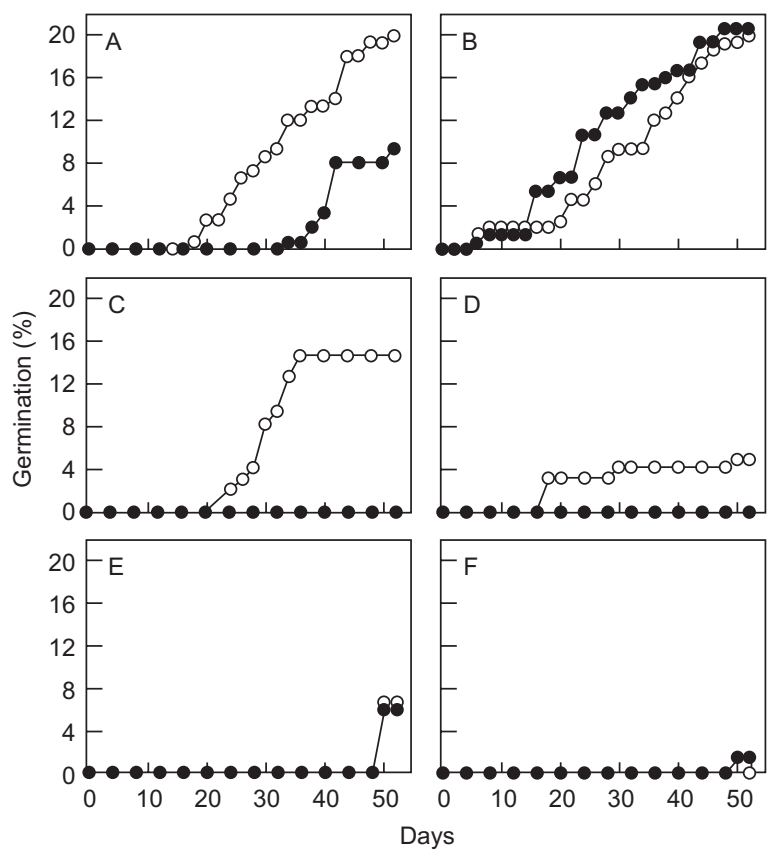

Fig. 5 - Germination of Psychotria barbiflora seeds stored at 4YC in darkness (A, C, E) and in cerrado soil in the cerrado at the Reserva Biológica e Estação Experimental de Mogi-Guaçu, Mogi-Guaçu, State of São Paulo, Brazil (B, D, F), for different periods: 1 (A, B), 3 (C, D) and 7 (E, F) months. Open symbols: germination at 25rC, in light; closed symbols: germination at $25 \mathrm{rC}$, in darkness. 


\section{DISCUSSION}

The cerrado soil where the fruits were buried is very poor in nutrients (Table 1) and highly porous (Table 2), so that water can easily go through and reach the artificially buried seeds. Thus in the absence of an impermeable coat, seeds can imbibe and begin the germination process.

Germination values of seeds of Vernonia herbacea stored at 4rC were always very low, thus it is difficult to conclude that the seeds are light sensitive and that storage in soil changed their photoblastism. The seeds were stored during a dry period of the year (Fig. 1), but the little rain that occurred in April, soon after the seeds were stored in soil, could be enough to start the germination process (the moisture content was up to $24 \%$ ). Achutti (1978) has shown that in Piptocarpha rotundifolia, another member of the Asteraceae from the cerrado, in 2,300 achenes only 6 of them possessed embryos. The production of a large number of achenes but with only a few embryos also occur in $V$. herbacea where only $15 \%$ of the achenes had embryos. Cesarino (1996) studied the germination of achenes of Vernonia cognata (which occurs in the same cerrado area at Mogi-Guaçu) and found the achenes maintained their viability for over 18 months if stored at 4rC but lost it after 10 months of storage at room temperature. The germination was never higher than $35 \%$, in light or darkness and the tetrazolium test showed a similar value of achenes with embryos. Thus, the large production of achenes with no embryos seems to be a common feature in the Asteraceae of the cerrado. This may not be very important since many of these species show vegetative propagation from their perennial underground organs (Carvalho et al., 1997).

The reason for the low values of germination in Psychotria barbiflora is at present unknown, but the analysis of the results obtained here shows that storage for 1 month in soil or at low temperature causes a decrease both of seed viability and of sensitivity to light. Plants of P. barbiflora with longistyle flowers produce a far larger number of fruits than plants with brevistyle flowers (Monteiro et al., 1991). In the present work the fruits used were from both kinds of plants.

With storage at 4rC the viability of seeds (achenes) of Bidens gardneri is maintained for long periods, as a few of them are still able to germinate when stored for over 8 years. No germination occurred with seeds stored for more than 9 years. No significant differences were found between germination in light and darkness for seeds stored at $4 \mathrm{rC}$ for different periods of time, including those stored for only 6 months. It is possible that the speed at which the seeds lose their light sensitivity depends, among different factors, on harvest batch: the seeds stored for 6 months (Fig. 3E) were collected in 1997 whereas seeds collected in 1995 (Figs. 2C, E) showed light sensitivity after storage at 4 rC for 6 and 9 months. Seeds of B. gardneri are light sensitive and this has been described before by Felippe (1990), who also showed that germination is very low in darkness for newly collected seeds and that germination values increase (in the dark) with time of storage (achenes stored up to 14 months). This could possibly be the case also for Vernonia herbacea. In the present work the light sensitivity was maintained with storage at low temperature for 9 months. Light sensitivity was lost much quicker when the seeds were stored in soil. The seeds were stored during August, a dry period (Fig. 1) although the seeds could imbibe with the small amount of water available and be able to germinate, if they were not light sensitive. Felippe (1980) showed that the effects of light, which promotes germination in Rumex obtusifolius and inhibits it in Cucumis anguria, can be counteracted by alternating temperatures. Bidens gardneri another light sensitive seed may behave in the same way as Rumex. Ortolani \& Pinto (1972) have shown that in Ribeirão Preto, State of São Pau-

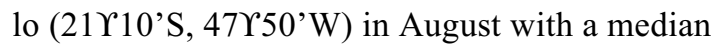
air temperature of 22rC (compare Fig. 1 showing that the air max temperature was around 30rC and the mininum around 15rC) alternating temperatures occurred in the soil at $5 \mathrm{~cm}$ deep (16rC at 8:00 h and 31rC at 16:00 h) and at $10 \mathrm{~cm}$ deep (19rC at 8:00 $\mathrm{h}$ and 30rC at 16:00 $\mathrm{h}$, but the temperatures were nearly constant at $20 \mathrm{~cm}$ deep (22rC and 24rC). As the seeds in this work were buried between 10 to $15 \mathrm{~cm}$ deep, some alternating temperatures almost certainly occurred. Thus, as shown for the buried intact seeds of Bidens gardneri and Vernonia herbacea the seeds could germinate because they were imbibed, lost their sensitivity to light and were exposed to alternating temperatures. It seems likely that during storage in soil, 
seed of the 3 species studied here, will, over a period of frequent rain (Fig. 1) imbibe and also lose their sensitivity to light at different rates. In this way as storage proceeds there is an increase in the number of germinated seeds in the soil. The lots of seeds used are from different populations in relation to photoblastism, they all imbibe (the moisture content of the intact seeds are 4 to 5 times the moisture content of seeds kept in refrigerator), but the different populations lose light sensitivity in different periods of time.

From the germination studies it can be concluded that Vernonia herbacea does not contribute for the formation of a seed bank in cerrado as the achenes germinate with the first rain. As some achenes of Bidens gardneri are still intact at 9 months storage in the soil and fruits of Psychotria barbiflora after 7 months, these two species may form a temporary seed bank in cerrado.

Acknowledgements - Are due to CNPq for financial support and research grants for the authors and to Alessandra M. Lopes and Daniela Trevizan for technical assistance. Thanks are also due to Prof. John E. Dale (University of Edinburgh) for correcting our mistakes in English.

\section{REFERENCES}

ACHUTTI, M. H. C., 1978, Aspectos morfológicos e anatômicos dos sistemas aéreo e subterrâneo e o óleo essencial das folhas de Piptocarpha rotundifolia (Less.) Baker (Compositae). Tese de Doutorado, Universidade de São Paulo, São Paulo, 212p.

BENNINGTON, C. C., McGRAW, J. B. \& VAVREK, M. C., 1991, Ecological genetic variation in seed banks. II. Phenotypic and genetic differences between young and old subpopulations of Luzula parviflora. J. Ecol., 79: 627643.

BERGE, G. \& HESTMARK, G., 1997, Composition of seed banks of roadsides, stream verges and agricultural fields in southern Norway. Ann. Bot. Fenicci, 34: 77-90.

CARVAlHO, M. A. M., ZAIDAN, L. B. P. \& DIETRICH, S. M. C., 1997, Growth and fructan content of plants of Vernonia herbacea (Asteraceae) regenerated from rhizophores. New Phytol., 136: 153-161.
CESARINO, F., 1996, Crescimento de Vernonia cognata Less., uma espécie herbácea de cerrado. Tese de Mestrado, Universidade Estadual de Campinas, Campinas, 76p.

CHAMPNESS, S. S. \& MORRIS, K., 1948, Populations of buried viable seeds in relation to contrasting pasture and soil types. J. Ecol., 36: 149-173.

DELOUCHE, J. C., STILl, T. W., RASPET, M. \& LIENHARD, M., 1962, The tetrazolium test for seed viability. Miss. Agric. Exp. Stn. Tech. Bull., 51: 1-63.

FELIPPE, G. M., 1980, Germination of the light-sensitive seeds of Cucumis anguria and Rumex obtusifolius: effects of temperature. New Phytol., 84: 439-448.

FELIPPE, G. M., 1990, Germinação de Bidens gardneri Baker, uma planta anual dos cerrados. Hoehnea, 17: 7-11.

LABOURIAU, L. F. G. \& COSTA, J. A. F., 1976, Objetivos $e$ instalações básicas de um laboratório de fisiologia vegetal. Academia Brasileira de Ciências, Rio de Janeiro, $59 \mathrm{p}$.

MANTOVANI, W. \& MARTINS, F. R., 1988, Variações fenológicas das espécies de cerrado da Reserva Biológica de Mogi-Guaçu, São Paulo. Rev. Brasil. Bot., 11: 101-112.

MANTOVANI, W. \& MARTINS, F. R., 1993, Florística do cerrado na Reserva Biológica de Mogi-Guaçu, SP. Acta Bot. Brasil., 7: 33-60.

MONTEIRO, R., NAKAJIMA, J. N., RIBEIRO, J. E. L. da S. \& TOLEDO, J. C., 1991, Morfologia e distribuição espacial das formas heterostílicas de Psychotria barbiflora DC. (Rubiaceae). Naturalia, 16: 137-146.

ORTOLANI, A. A. \& PINTO, H. S., 1972, Temperatura do solo. In: A. C. Moniz (ed.), Elementos de pedologia, Editora Polígono, São Paulo, p. 59.

RUGGIERO, P. G. C. \& ZAIDAN, L. B. P., 1997, Estudos de desenvolvimento de Viguiera robusta Gardn., uma Asteraceae do cerrado. Rev. Brasil. Bot., 20: 1-9.

SNEDECOR, G. W., 1962, Statistical methods. Iowa State University Press, Iowa, 534p.

SIMABUKURO, E. A., ESTEVES, L. M. \& FELIPPE, G. M., 1998 , Fern spore morphology and spore rain of a preserved cerrado region in south-east Brazil (Reserva Biológica de Mogi-Guaçu, São Paulo). Amer. Fern. J., 88: 114-137.

ZAIDAN, L. B. P. \& FELIPPE, G. M., 1994, Flowering of cerrado plants: experiments in semi-controlled environmental conditions. Flowering Newsletter, 18: 4-11. 